\title{
The Children's Literature of Indigenous Small-Numbered Peoples of the Krasnoyarsk Krai
}

\author{
Natalia M. Libakova and Kseniia I. Petrova* \\ Siberian Federal University \\ 79 Svobodny, Krasnoyarsk, 660041, Russia
}

Received 16.03.2016, received in revised form 21.06.2016, accepted 18.08.2016

The article deals with the analysis of fairy tales as the basic form of the children's literature of indigenous small-numbered peoples of the Krasnoyarsk Krai. The fairy tale is considered as a specific prosaic type of folklore, which focuses on preservation and translation of the unique values of some or another culture as well as on the generation ties maintenance. Through the method of content analysis done for the Evenk, Nganasan, Nenets and Ket tales, the authors characterize the world view peculiar to the culture of each of these peoples and define their family models. To the family model a particular attention is given, since namely the family represents a primary space for the personal formation, development of their ethnic identity and system of values. Moreover, the fairy tale is considered as an especial form, which gives an opportunity to protect the uniqueness of indigenous small-numbered peoples living in the Krasnoyarsk Krai in the context of globalization, and harmoniously balance the values of traditional culture and modern achievement of the civilization.

Keywords: children's literature, fairy tale, indigenous small-numbered peoples, the Krasnoyarsk Krai, the North, world view, family model, content analysis.

This work has been done under the grant research by Kranoyarsk Regional Support Fund for Scientific and $S \& T$ Activities, with the theme "Corpora formation of the original texts for children (written in the Evenk, Nenets, Nganasan and Dolgan languages) as the way to preserve the unique cultural heritage of indigenous small-numbered peoples of the Krasnoyarsk Krai.

DOI: 10.17516/1997-1370-2016-9-9-1977-1993.

Research area: theory and history of culture.

Nowadays indigenous small-numbered modern civilized world are seeking to replace the peoples of the Krasnoyarsk Krai represent a ones belonging to traditional cultures.

In this context, it is relevant to solve the subject for many social, psychological, medical, cultural and other researches some way or another aimed at maintaining the number of population, their unique culture in terms of an increased cross-cultural interaction when values of the problems of how, given all the civilization's achievements which, indeed, raise the living standards for indigenous people living in severe natural condition, to preserve their unique culture

(C) Siberian Federal University. All rights reserved

* Corresponding author E-mail address: trognonulia@gmail.com 
and support forming a positive ethnic identity in indigenous communities.

One of the ways to answer this question is to preserve the national literature as a center of values and senses of the traditional culture. In this context, one should take the analysis of role and meaning of children's literature belonging to indigenous peoples of the Krasnoyarsk Krai, i.e. of the folk tales as a specific genre found in every traditional culture. A fairy-tale, which is told by the older generation to children, meets a range of problems: it connects generations, transfers ethnic traditions related to different spheres of life, i.e. social, economic or spiritual one. Fairytales visualize the models of relationship between elders and youngsters and an ideal family pattern; it also translates craft traditions (hunting and fishing) and depicts the worldview and interaction between members of different global economies.

The target of this research is the fairy tales of indigenous small-numbered peoples of the Krasnoyarsk Krai (Evenkis, Nganasan people, Nenets and Ket people) as a basic element in the children's literature of these peoples; and as a recording form for the traditional family pattern and cultural worldview the existence of which is a crucial step in the preservation of indigenous peoples' original culture. A content analysis was conducted to study the features of tales considered as the family pattern and cultural worldview medium.

The notion of "children's literature" traditionally means a part of the literary heritage targeted at children and aimed at educating, mindset formation and aesthetic perception developing.

Various aspects of the children's give consideration to both national and foreign researchers. Thus, Lusy Pearson on the basis of discourse analysis of the British children's literature within a wide social context highlights criteria for the "good" and "bad" children's literature and describes the contribution of major and small publishing houses into the children's literature development (Pearson, 2013).

Considering canonical literary works by Charles Dickens, Charlotte Bronte, William Makepeace Thackeray, Abraham Stocker and Robert Lois Stevenson in the context of gender approach, Claudia Nelson studies the images of children and adults together with the models of their relations (Nelson, 2012).

K. Jerome and K.A. Sweeney examine the problem of interaction between children and foster parents and focus on the analysis of parent images depicted in the English literature targeted at children aged $4-8$ (Jerome, Sweeney, 2014).

The national studies of children's literature address different issues: both general (Voskoboinikov, 2012) and specific ones. In particular, they include the analysis on gender aspects of children's literature (Utkina, 2012); literature resources as the means of tolerance encouragement (Kicheva, 2015); the family image formed in literary works for children (Gurskaia, 2012); and also this literature is considered as a way to learn the environment (Savinova, Leontieva, 2014).

The work by A.Iu. Isakovskaia (Isakovskaia, 2012) is dedicated to the studies of tales as a special literary genre: the author analyses the stories and their adaptation in other cultures and provides insight into the mechanism of cross-cultural communication and literary ties development.

Numerous national researches are focused on the study of folk tales which have no particular author and present a part of the folklore heritage of one or another nation. The scientists look into the materials obtained during the folk expeditions (Kim, 2011); investigate special aspects of the plots and basic motives in the stories (Osipova, 2015); consider the images of characters as the expression of unique cultural identity (Zakharova, 2015). 
A.A. Kim analyzes Nganasan and Ket prosaic texts. In his work "The folklore analysis and classification of the prosaic Khanty texts collected by Steiniz in 1936" (Kim, 2011) the researcher conduct the folklore analysis and classify the plot structure of a number of prosaic Khanty texts written and translated into the Russian languages by V. Steiniz in 1936 and apply a new approach on the folklore classification basing on the plot action. Besides, the author addresses the analysis of prosaic texts belonging to other Northern peoples - Selkup, Ket and Nganasan peoples.

The Russian researchers M.A. Kolesnik (Kolesnik, 2014), K.V. Reznikova (Reznikova, 2016), N.N. Pimenova (Pimenova, 2014) and T.B. Vladislavleva (Vladislavleva, 2011) investigate the cultural heritage of indigenous small peoples of the Krasnoyarsk Krai and mark a particular importance of folklore for the process of positive ethnic identity formation in the modern representatives of these peoples as well as for the preservation of their cultures.

Apart from analytical researches, descriptive papers, which one way or another reveal the special patterns of folklore and, in particular, of fairy tales, are also still important. Thus, M. Voskoboinikov (Voskoboinikov, 1967) ranged the information about the Evenks' folklore obtained both during the pre-revolutionary and soviet periods; and also classified their spoken poetry where tales serve as a crucial link. Moreover, the author concentrates on the description of specific features of the Cisbaikalian Evenks' world perception and view.

In the researches dedicated to the analysis of Evenki mythological consciousness (Archakova, 2006), O. B. Archakova considers tales with the intention to reveal the worldview encoded inside them. In particular, the author finds that a regular feature or a fundamental of the Evenkis' worldview is the idea of fight or resistance. Besides, within this work she calls her attention to the references to the Russian ethos and on the basis of comparison forms an image of "the Russian in the Evenk culture" and of "the Evenki in their relationship to the Russians".

Ye. T. Pushkariova (Pushkariova, 2003) provides the analysis of a significant amount of the Nenetz folklore and ethnographic material, which reveals their beliefs about the world views belonging to different groups of traditional culture guardians. The researcher investigates heroic songs and mythic tales; comprehensively considers the world order presented in the Nenetz folklore.

G.T. Polenova, a Russian scholar, in her article "What can Ket fairy-tales tell us about?" (rus. - "O chem mozhet rasskazat ketskaia skazka?") considers the Ket tales as an expresser of the specific things about living and beliefs of Ket hunters; demonstrates the most archaic aspects of the Ket language delivered by the tales; gives some extra linguistic data which allow to get an insight into the tale, i.e. the description of chum (tent) design or home-fire sacrality (Polenova, 2015).

Thus, basing on the analysis of submitted researches, we shall mark that the most important element peculiar to the children's literature in traditional cultures of indigenous peoples is a part of their folklore heritage - a fairy-tale considered as a common form of values delivery and intergenerational ties maintenance. Addressing research tasks, the scientists turn to fairy tales as to the source of knowledge about the culture of indigenous small-numbered peoples.

As a sign of this statement, we will bring the specific nature of the cultural world view and family model represented in the tales of Evenks, Nganasans, Nenets and Kets to the light through the content-analysis.

Being a multilevel system of the cultural notions and images which forms the world perception and confident in the right guidance, 
the cultural world view is critical for the ethnic identification of a person done through involving into the cultural world view and understanding of oneself as a part of it. Clearly, a significant role in the cultural world view building is played by the family, since it namely forms a primary value system and core of personal individuality. Particular characteristics of the family model are pre-determined by those natural conditions where the people live, and by a specific type of economic activities peculiar to the ethnos.

To meet this target, we have chosen the content analysis which provides an opportunity to consider the content through qualitative and quantitative assessments. The bottom line is that we select a certain search category (a concept, which is in this case presented by all the notions related to family) and analyze it either from the general number of references (then the quality of information is determined by its quantity) or from the items characterizing this concept (then the method is regarded as a qualitative) (Dmitriev, 2005). Through the example of four fairy tales belonging to the indigenous small-numbered peoples of the North this approach would shape the basic family models typical for the Evenki, Nganasan, Keti and Nenets peoples.

Apart from this, since the tale is yet a certain medium for "the world view" of these peoples, so basing on the complete conceptual analysis of the tales, we have found the key elements of the "cultural world view": its features, the world structure, the culture's aims, its members and ideal hero image. Depending on what aspect of the literary work is covered, different methods of the literary works analysis are used. Hermeneutic analysis has provided an opportunity to interpret texts, to reveal their implications and hidden meanings - a backbone for the world view characteristics identification. Lexical analysis has been used to reveal the features of "closeness" and "openness" towards other nations and opportunities for cultural exchange. We have also practiced the analysis of artistic space and time; archetypical approach, which allows distinguishing main characters of the world view and identifying its perfect member); sociological analysis of the work through which the fundamentals of "social atmosphere" have been formed.

\section{The analysis of Evenk fairy tales}

To define the model of Evenk family, the tale "Brave Khurkokan" (rus. - Khrabrii Khurkokan") has been analyzed: we have marked the features of each character belonging to the category "family"; defined their relationship types and counted the number of references of the basic family roles, such as father, mother, daughter, son and etc. All the data have been recorded and showed in the Table 1.

On the basis of the received information one can designate some specific features of the Evenk family:

- The family elders' description does not lay emphasis on their gender, i.e. the father is characterized as "Evenk", but there are no references to him as a "man" or "husband". The mother is shown neither as a "mother" nor as "woman", but as a "wife". These characteristics are peculiar only to the grandmother on the father's side - an "old woman" (starukha). At the same time, the children are characterized by their gender: daughters are called "little girls" (devochki) and then "young girls" (devushki). As for the main character - Khurkokan - so nothing is said about his gender, but he is only called by the name or as "son" (syn).

- The relationships between older and younger generations include words emphasizing their kinship - grandmother, grandson, granddaughters. So, it is possible to conclude, that this ethnos practiced children's upbringing by the older generation. There also is the type of relationship between the children, since the 
Table 1. Results of the content analysis of Evenk tale "Brave Khurkokan" (rus - "Braviy Khurkokan")

\begin{tabular}{|c|c|c|}
\hline \multirow{5}{*}{$\begin{array}{l}\text { Characters } \\
\text { description }\end{array}$} & Father & Father, a poor Evenk (Otets, bedniy Evenk) \\
\hline & His mother & An old woman, a grandmother (Starukha, babushka) \\
\hline & Mother & Wife (Zhena) \\
\hline & Daughter & Daughters, girls, young girls (Dochki, Docheri, Devochki, Devushki) \\
\hline & Son & A son, Khurkokan; a grandson (Syn, Khurkokan; vnuk) \\
\hline Relationships & \multicolumn{2}{|c|}{$\begin{array}{l}\text { In the family: "Zhil odin bednii Evenk so svoei semiei. Byla u nego mat' starukha, zhena i dve } \\
\text { docheri. A kogda dochki podrosli nemnogo, rodilsia esche i syn". } \\
\text { Between the generations: "Ispugalas babushka, chto Nurgovul' ee vnuchka ubiet" } \\
\text { Between the children: "Stanesh bolshim - poidesh svoikh sester viruchat"; "...Dogadalsia } \\
\text { Khurkokan, chto devushki eti - ego rodnie sestri, obradovalsia. Nakormili oni brata i } \\
\text { govoriat..." }\end{array}$} \\
\hline \multirow{14}{*}{$\begin{array}{l}\text { Total } \\
\text { references: }\end{array}$} & Father (Otets) & 1 \\
\hline & Husbnad (Muzh) & \\
\hline & Man (Muzhchina) & - \\
\hline & Mother (Mat') & 1 \\
\hline & Wife (Zhena) & 1 \\
\hline & $\begin{array}{l}\text { Woman } \\
\text { (Zhenschina)* }\end{array}$ & - \\
\hline & Son (Syn + plurals) & 1 \\
\hline & Daughter (Doch) & 4 \\
\hline & $\begin{array}{l}\text { Family: parents } \\
\text { (Semia: roditeli) }\end{array}$ & $2(3)$ \\
\hline & Old man (Starik) & - \\
\hline & $\begin{array}{l}\text { Old woman: } \\
\text { grandmother } \\
\text { (Starukha: } \\
\text { babushka) }\end{array}$ & $2(4)$ \\
\hline & $\begin{array}{l}\text { Grandson/ } \\
\text { granddaughter } \\
(\text { Vnuk/vnuchka) }\end{array}$ & 3 \\
\hline & Brother (Brat) & 1 \\
\hline & Sisters (Siostri) & 4 \\
\hline
\end{tabular}

text contains such words as "brother" (brat) and "sister" (sestra).

- There are such expressions as "family" and "parent". It indicates some social units division, when the members can identify "their", i.e. "my family" and etc.

- The frequent use of possessive pronouns such as "their" and "own".

Thus, the family identification is as follows: it contains the father, his mother (the grandmother), his wife (not the mother!), daughters as sisters and granddaughters and his son, who in this case is the main character and, therefore, has the name. The family is represented by itself and it has a perfectly clear kinship.

To describe the cultural world view of the Evenks, we have also analyzed the tale "Agdigrom". This story tells us about a boy named Agdi-grom, who decides to defeat Krilatiy, a creature, which lives in the sky and eats people. The kinship community, where he lives, does not believe in his power, so he has to wander in order 
to gain the experience and kill this creature. The main character meets powerful women who give him iron wings, and then, searching for Krilatiy's living place, faces with obstacles represented by an old woman, partridge and old man. The fairy tale ends with the main character finds Krilatiy's place, kills him and reaches into the sky. The ending scene is capturing of the moment of the never-ending fight between Adgi-grom and Krilatiy.

We can identify several cultural characteristics expressed in this tale:

\section{Feeling of timelessness:}

This feature is expressed by the absence of climax; the characters are involved into an endless fight. Besides, there is a clear timelessness in the characters' lives, excepting the process of initiation of the protagonist.

2. Engagement into the structure of the enemy world order:

The main enemy, despite the fact that he devours men, does not awake any fear or disgust; he is necessary for the main character to appear as a hero, but he is not felt as an external force.

3. Structured social order, where powerful women take leading positions:

The main character is born in the tribe, but during the wandering he meets 8 different tribes headed by the powerful women. The eldest members are characterized by their wisdom.

4. Clear process of personal development which includes the aspect of wandering:

The protagonist undergoes the process of initiation fixed in time. Only by 20 years old, he becomes ready for the battle and able to go into another world.

5. Surrounding space is integrated into the peoples' live:

The lead character pulls through the obstacles caused by the natural forces, i.e. through swamps or forests. On the way he meets an animal and talks to it.
This fairy tale explains such natural phenomenon as thunder, storm, lightning as the process related to people, or, as the phenomenon caused by the fight between them and Krilatiy.

The world structure. This fairy tale presents the simplest vertical scheme of the world structure. People live on earth closely with the nature and in a well structured society together with its values. There also are the sky inhabitants, i.e. either the heroes who have formerly lived on earth, or the characters who come against people. Besides, they are able to affect the live and activities of ordinary people.

The purpose of activity: to build a religious connection between humans and the Heavenly world.

Algorithm: spiritual upbringing through wandering and development with the wisest ones; physical education through skills exercising.

Participants: a person who on their own seeks to establish the religious tie with the world; the society; powerful women as the authorities for the society along with its eldest members; the natural forces as advisers.

An ideal person is the man who is can independently in the process of his own education communicate with the Heavenly world.

Considering the received data, we can define the key idea characterizing the Evenk society: it is the concept of continuity, of a permanent intergenerational change and tie, where every child who initially plays the role predetermined by their gender (their social sex) should undergo the process of development and, thus, gradually become a member of the society and built their own family, i.e. another social unit. At the same time, this society directly depends on the natural forces, considered as dominating ones, as well as on the experience of the older generation and ancestors.

\section{The analysis of Nganasan fairy tales}

To assess the Nganasans family model, we have chosen the tale "The Lake of Death". This 
story focuses on lives of two families headed by Boro-hala, a father of the first family, and Khansi-tala, a son from the other family. The tale begins with Boro, his daughter and Khansi going for hunting, where Boro sees seven polled deer which transform into a woman and then into a burbot; thus Boro understands his death coming. Having decided to be seized, Boro comes to the Lake of Death, his daughter and Khansi follow him. The Lake takes Boro and says that it would also take children of Khansi and Boro's daughter. In several years, one of their children, a shaman, kills domestic deer while hunting, a female and a male, after which his parents die. In the end the shaman finds a new family and gets all the goods.

Grounding on the material received through the content analysis (Table 2), we can identify a set of specific features for the Nganasan family:

- Those characters represented as heads of the family stand apart since they have the names. The first-degree relatives, i.e. the wife and children, also bear their father's name, e.g. "Boro's daughter", "Khunsi's mother and father, and Boro's wife". In the case of marriage, apart from becoming a wife, the daughter is also marked by her belonging to the father: "Khunsi, his wife, a daughter of Boro". Still, this feature is peculiar only for daughters (and only for those who are under specific age); Khunsi's sons are not characterized by such a kinship.

- The family description does not include the word "family" per se: the quantitative characteristics is far more important, e.g. "Five people began to live together";

- There is a clear distinction between the generations, since people of the secondary generation are characterized as old people: "Two old woman and an old man stayed"; "The olds, Khunsi's mother and father and Boro's wife"; "I am old" (Boro says about himself);
- Reference to gender is also crucial for the tale: there is a scheme like "husband - man father" or "wife - woman - mother", "daughter girl" or "boys - sons". This scheme can be explained by the fact that the gender identification implies a special behavior pattern and type of activity given by the sexual character.

- Hierarchy in the list of family members: "Khunsi, his wife, a daughter of Boro, their son-shaman and other two sons", where the sonshaman is mentioned above his two brothers

- Ancestors have been mentioned once: Boro says "my ancestors". In fact, the possessive pronoun "my" is rarely used even in relation to the parents and children: Boro's daughter only one time has called his "my father". Moreover, this reference appears even after Boro's death. The father also has said "my daughter" only once, but in this case he has used this expression within the context of his daughter's marriage.

Considering the total number of references, we shall note that such characteristics as "mother", "woman", "son" and "daughter" are most frequently mentioned. Still, it is worth saying that the family head is more often than not called by his name, e.g. Boro, or Boro-tala, have been used for 21 times in this tale; Khunsi, or Khunsi-tala for 13 times. Thus, there is such family model, which has the head with his reference without any description as a husband or father; a woman characterized by her role as the mother; and there are children, i.e. sons and daughters.

Based on the analysis of this fairy tale, the following main features which determine the Nganasans' cultural world view have been defined:

\section{The culture's character:}

\section{Hunting as the cultural basis.}

Hunting is the main activity and measurement of the human life. Through the experience in selfreliant hunting the family head is named and the essential human abilities to life are developed. 
Table 2. Results of the content analysis of Nganasan tale "The Lake of the Death" (rus. - Ozero smerti)

\begin{tabular}{|c|c|c|}
\hline \multicolumn{3}{|l|}{ Family 1} \\
\hline \multirow{5}{*}{$\begin{array}{l}\text { Characters } \\
\text { description }\end{array}$} & Father & Boro-tala (boro); I'm old (Ya stariy) \\
\hline & Mother & Wife; old woman (Zhena; starukha) \\
\hline & Son & - \\
\hline & Daughter & $\begin{array}{l}\text { Daughter, girl, Boro's daughter, my daughter, woman (Doch', devka, doch' } \\
\text { Boro, moia doch', zhenschina) }\end{array}$ \\
\hline & $\begin{array}{l}\text { Fiance and his } \\
\text { family }\end{array}$ & $\begin{array}{l}\text { Fiancé -Khunsi-tala, Khunsi, son-in-law, husband (Zhenikh-Khunsi-tala, } \\
\text { Khunsi, ziat', muzh) } \\
\text { His family: "mat' est', otets”; "Vsekh tozhe troe”; "starukha i starik”. }\end{array}$ \\
\hline Relationships & \multicolumn{2}{|c|}{$\begin{array}{l}\text { In the family: "U Boro-tala olenei mnogo. Zhena u nego i doch'. Syna net. Vsekh troe". } \\
\text { "Dve staruhi i odin starik ostalis"” } \\
\text { "Khunsi i ego zhena" } \\
\text { With the past: "moii predki"(eng. "my ancestors") }\end{array}$} \\
\hline \multicolumn{3}{|c|}{ ( } \\
\hline \multirow{4}{*}{$\begin{array}{l}\text { Characters } \\
\text { description }\end{array}$} & Father & Husband, man, father (Muzh, muzhchina, otets) \\
\hline & Mother & Wife, woman, mother (Zhena, zhenschina, mat') \\
\hline & Son(s) & $\begin{array}{l}\text { Young men - sons; middle son - his son - young man (Parnei-synovei; } \\
\text { srednii syn - syna svoego - paren') }\end{array}$ \\
\hline & Daughter & Daughter, girl (Doch', devochka) \\
\hline Relationships & \multicolumn{2}{|c|}{$\begin{array}{l}\text { Daughter and father: "moi otets govoril" } \\
\text { Daughter and her sons: "Detei otdav, ia ochen' muchitsia budu" : } \\
\text { Towards the children: "mat' i otets" } \\
\text { In the family: "Stali zhit' vmeste piat' liudei", } \\
\text { Between the generations: "stariki, otets i mat' Khunsi i zhena Boro"; "U Khunsi i ego zheny } \\
\text { rebjat mnogo rodilos'”; "Khunsi, ego zhena, doch' Boro, ikh syn-shaman i esche dva syna"; } \\
\text { "Nash (vash) otets" (about Boro) }\end{array}$} \\
\hline \multirow{11}{*}{$\begin{array}{l}\text { Total } \\
\text { references: }\end{array}$} & Father (Otets) & 6 \\
\hline & Husbnad (Muzh) & 2 \\
\hline & Man (Muzhchina) & 1 \\
\hline & Mother (Mat') & 13 \\
\hline & Wife (Zhena) & 3 \\
\hline & $\begin{array}{l}\text { Woman } \\
(\text { Zhenschina })^{*}\end{array}$ & 13 \\
\hline & Son (Syn + plurals) & 12 \\
\hline & Daughter $($ Doch $)$ & 8 \\
\hline & Family (Semia) & 0 \\
\hline & Old man (Starik) & 2 \\
\hline & $\begin{array}{l}\text { Old woman } \\
(\text { Starukha })\end{array}$ & 2 \\
\hline
\end{tabular}

*The total number of references to the female character (not only a woman as a particular member of the family)

This fairy tale particularly tells us about a hidden solo hunting. One of the key moments is that having met a borus, the father Boro-tala starts this hidden hunting for Khunsi-tala, but
Khunsi-tala stops him. When Boro-tala comes to his senses, he understands that the death will come soon and, thus, gives his entire household to Khansi-tala. Therefore, there is cultural feature -a 
special character of this peoples' life - continuity, when the strongest and smartest person becomes the family head, and those who see an enemy in the man next to them accept the coming death.

2. Culture sustainability through the family head

Every family has the head, who is identified through his skills in hunting or abilities in communication with the Powers. In these tales the family heads are named, so as to mark their superiority over the other members of the family.

3. Perception of the world order as a living chain (through the human imperceptions of external processes as artificial ones)

Interaction between all aspects of the human life comes naturally. For example, at the moment when Boro-tala prepares for the death, he comes to the Lake and says: "Lake! Eat me! Open your throat". One can conclude that these people percept all the processes existing in the world in a natural way.

\section{4. "Closeness" from other cultures}

This feature is expressed through the tale language. Both lexis and sentences structure demonstrate that the Nganasan culture is quite closed and would rarely come into any cultural exchanges.

\section{5. "Closeness" in terms of the family}

The fairy tale describes two small-numbered families. There is no other reference to the Nganasan families, and, consequently, there is no exchange with the members of other families.

The world structure. The text describes a two-part structure of the world. The Lower World is represented by the Lake of Death and its residents, e.g. borusis. The Upper World is inhabited by people and animals. The heaven world is not mentioned in this literary work, but the shaman tells us about the existence of powerful spirits.

The purpose of activity: to live with the Powers' will in harmony.
Algorithm: to meet the conditions set by the Powers (by the Gods, Spirits and etc.); and also to do hunting as a way to support one's life for satisfying the Powers.

Participants: the family (or a number of closely related families) headed by the oldest, strongest person, able to communicate with the Spirits; the animal world as an indicator of the Powers appearance or as a bag.

An ideal person is one that lives in harmony and wisely understands the Powers' messages.

The Nganasan life is based on the view of man as the family head around whom the social life is built. He set a hierarchy and forms a cohesive and closed to external influence family around him. The main reason for such househead identification is his physical advantage over members of the society, his experience and ability to adequately respond to the Powers' influence.

\section{The analysis of Ket fairy tales}

The description of Ket family is based on the analysis of "A Woman and Witch"(rus. "Zhenschina i Chertovka") fairy tale. All the received information is presented in Table 3.

The Ket family has the following features:

- In this case we consider the family model combined of two couples with children, but quite surprisingly, male and female characteristics contain only their gender and roles (as spouses) husbands and wives. Parenting qualities are not mentioned.

- It is noted that household and educational functions are performed only by women. According to the plot, men go for hunting in the morning. The story focuses on the women, and the biggest part of references are related to them.

- The younger generation is characterized in a general way - as "children". There are no clear references to the features of each child.

- Hierarchical pattern: for example, «... spasla zhizn' svoikh detei, zhizn' svoei podruge $i$ sebe ...». It can be assumed that in this type of the 
Table 3. Results of the content analysis of Ket tale "A Woman and Witch" (rus. - "Zhenschina I Chertovka")

\begin{tabular}{|c|c|c|}
\hline \multirow{3}{*}{$\begin{array}{l}\text { Characters } \\
\text { description }\end{array}$} & Men & Husbands (Muzhia) \\
\hline & Woman & Wives (Zheni) \\
\hline & Children & \\
\hline Relationships & \multicolumn{2}{|c|}{$\begin{array}{l}\text { "Zhili dve semii. V semie bylo dvoe muzhchin, dve zhenschiny i dvoe detei". } \\
\text { Between the families: "Vtoraia zhenschina, kotoraia byla starshe svoei podrugi". } \\
\text { Hierarchy: "spasla zhizn' svoikh detij, zhizn' svoei podruge i sebe". }\end{array}$} \\
\hline $\begin{array}{l}\text { Total } \\
\text { references: }\end{array}$ & Father (Otets) & - \\
\hline & Husbnad (Muzh) & 1 \\
\hline & Man (Muzhchina) & 4 \\
\hline & Mother (Mat') & - \\
\hline & Wife (Zhena) & 1 \\
\hline & $\begin{array}{l}\text { Woman } \\
(\text { Zhenschina)* }\end{array}$ & 10 \\
\hline & Son (Syn+plurals) & - \\
\hline & Daughter (Doch) & - \\
\hline & Family (Semia) & 2 \\
\hline & Children (Deti) & 5 \\
\hline
\end{tabular}

*The total number of references to the female character (not only a woman as a particular member of the family)

family individual demands are put on the back burner: the first place is taken by the children's needs, by the relatives' ones and only then - by personal.

- Children's belonging to their parents is also emphasized: there are the possessive pronouns such as "their" and others.

The Ket people represent the type of integrated family, where educational functions are performed by the women and the fathers do not participate in upbringing. The parenting skills are also not so vivid: there is some kind of distance and no stress on the bloodline. Any emphasis on the characters of any given child is also lost.

This part of the research concerning the Ket's cultural world view is based on the analysis of the fairy tale called "Yeratnik". The story focuses on the fight between a childless woman and evil spirit called Yeretnik. This woman stays in the chum to help the mothers when all the men are at hunting. In the forest she meets Yeretnik, an evil spirit, which threatens to kill all residents living in the chum. Using some tricks, the woman persuades people to follow the hunters, while she stays to fight with the evil. With the help of a puzzle, she runs away from the Spirit, it scours after the woman, but get into a trap. The tale ends with the woman saving and her narration about this story to all people.

\section{The culture's character:}

1. Representation of the Spirit World as an external or as "harmful" one in relation to the human life:

In the human life the Spirit World not only fails to be expressed as a divine manifestation, but also does not represent an internal or natural obstacle in the life. Firstly, the evil spirit Yeratnik does not belong to the Ket mythology, and secondly it acts as a naïve and cheated character.

2. Lack of fatalism in the human life (a person can change the fight rules):

The tale does not say about a divine predetermination, while the same order is 
demonstrated only within the system of social organization. That is why, the motive of fight is perceived only as passing artificial obstacles for the comfortable living of the community. There are no certain rules in the fight: the main character uses tricks and traps, what is untypical for a good heroine.

3. Inclusion of elements taken from other cultures as the result of cultural exchange:

The literary language has some "marks" of the influence brought by other cultures: it can be both the plot structure and prototype for the main "villain". These features can be explained through the openness of this culture to the cultural exchange with other peoples.

4 . Ability of the human to adapt to the natural elements:

This fairy tale does not include the nature deity made by a man. The nature is understood as the means for the human values achievement (for their safety and comfort).

5. Social order as a prototype for the divine order

Apart from building the society on the basis of labor division according to the gender (a man is a hunter and supporter; a woman is a mother and hostess), the living rules of this society reflect the main social moral orientations for the people, i.e. caring for their relatives and sacrificing which are implied in the main heroine's character.

The world structure. This work demonstrates two words: the Human World with its clear social division into functions and the Spirit World which is little understood by the people - it is "external" in relation to them and, thus, not included into the natural chain of human life.

The purpose of activity: to live in the community and protect it from the evil spirits through fighting.

Algorithm: demonstration of all the human characteristics during the fight: not only physical, but also mental ones; a chance to defeat the evil spirits using cheating and tricks.

Participants: any member of the society who is ready to protect their home and become a hero; the community where they live and spirits as external "enemies".

An ideal person is one that uses any way to struggle and independently determines their destiny.

All in all, taking into consideration the analysis, we say that the Kets are quite closed on themselves. The tales demonstrate those relationships when the person is mainly aimed at surviving and adaptation. The society builds a certain order, but at the same time does not give to the man any role except for the ones predetermined by the nature. Personal needs become invisible. The life revolves not even around the family, but around a group of people, each member of which plays a certain role.

\section{The analysis of Nenets tales}

To consider the next, Nenets family model we have examined the tale "An Old Man and His Daughters" (rus. - "Stariki docheri"), which says about the girl switching to her husband and, thus, shows two types of the family. All the results can be seen in Table 4.

The Nenets family has the following characteristics:

- Parenting kinship: daughter's relation to her father is expressed (e.g. "starikova doch".

- Generation difference is emphasized: the family's mother and father are called an old man and woman. Considering the story, we can suggest that this is a way to underline their children's maturity and readiness to form a new family.

- Since in this case the tale says about three female characters (daughters), so the number of common references includes numerous characteristics such as "a young girl" (not woman!), "a girl" and "a wife" as 
Table 4. Results of the content analysis of Nenets tale "An Old Man and His Daughters" (rus. - "Starik i docheri")

\begin{tabular}{|c|c|c|}
\hline \multicolumn{3}{|l|}{ Family 1} \\
\hline \multirow{2}{*}{$\begin{array}{l}\text { Characters } \\
\text { description }\end{array}$} & Father (Otets) & An old man, father (Starik, otets) \\
\hline & $\begin{array}{l}\text { Daughters } \\
\text { (Docheri) }\end{array}$ & $\begin{array}{l}\text { Daughters (Docheri): elder daughter, middle daughter, small daughter } \\
\text { (starshaia doch', sredniaia doch', mladshaia doch'- “...u menia } \\
\text { posledniaia doch', liubimaia”); young girl, old man's daughter (devushka, } \\
\text { starikova doch') }\end{array}$ \\
\hline Relationships & \multicolumn{2}{|c|}{$\begin{array}{l}\text { "zhil starik s tremia docher'mi". } \\
\text { "Menia otets prislal, chtoby ty vzial menia v zhiony" }\end{array}$} \\
\hline \multicolumn{3}{|l|}{ Family 2} \\
\hline \multirow{3}{*}{$\begin{array}{l}\text { Characters } \\
\text { description }\end{array}$} & Family head & Koruta, the Master of Winds (Khoziain vetrov Kotura) \\
\hline & His mother & Old woman (silver-haired woman) (Starukha (sedaia starukha)) \\
\hline & Daughters & Young girls (Devushki) \\
\hline Relationships & \multicolumn{2}{|c|}{$\begin{array}{l}\text { "Pomogi mne, devushka", _ prosit starukha" } \\
\text { "I materi moei, i chetyriom sestram moim ponravilas', } \\
\text { "Bud' moei zhenoi! Ostavaisia zhit'v moiom chume!" }\end{array}$} \\
\hline \multirow{11}{*}{$\begin{array}{l}\text { Total } \\
\text { references: }\end{array}$} & Father (Otets) & 5 \\
\hline & Husbnad (Muzh) & - \\
\hline & Man (Muzhchina) & - \\
\hline & Mother (Mat') & 1 \\
\hline & Wife (Zhena) & 2 \\
\hline & $\begin{array}{l}\text { Young girl } \\
(\text { Devushka) }\end{array}$ & 38 \\
\hline & Son $(S y n+$ plurals $)$ & \\
\hline & Daughter (Doch) & 19 \\
\hline & Family (Semia) & - \\
\hline & Old man (Starik) & 13 \\
\hline & $\begin{array}{l}\text { Old woman } \\
\text { (Starukha) }\end{array}$ & 13 \\
\hline
\end{tabular}

the expression for their further status. Still, in relation to the male characters there is no information either about their gender, or about their roles: the first family calls them "father" or "old man"; the second family head is mentioned by his name - Kotura - 32 times, though his house-head is emphasized quite frequently: "Kotura prinios v chum sirie olenii shkuri i velel devushke sshit' emu $k$ vecheru odezhdu”.

- There is no such abstract notion as "children". Each child has their own character: elder daughter, middle daughter and small daughter - “...u menia posledniaia doch', liubimaia”.

- There a plenty of possessive pronouns. For example: 'Bud' moei zhenoi! Ostavaisia zhit'v moiom chume!" or "I materi moei, i chetyriom sestram moim ponravilas". It reflects the feeling of kinship which appears in the family context. But it's remarkable that the word "family" per se is not mentioned at all.

The Nenets tale has a clear reflection of the kinship between parents and children; also it underlines the age difference between generations, when the parents are called "olds" 
(this is the way to show their children's maturity). Each child has their own characteristics: their description includes the gender.

To outline the Nenets cultural world view, we have considered the tale "Two Brothers". It tells us about the life of two brothers left by their mother. They decide to hit the road to search for other people. One of them goes on the left side of the river, and the other - on the right side. Separately, they cope with challenges, but soon they meet people, learn from them their knowledge and culture. In several years they marry and return in their own chum together with their wives, meet each other and only after "recognition" become a single family.

\section{Life style features:}

\section{Importance of the kinship community:}

The brothers' trip is aimed at meeting followed by coming back home that says about their understanding of a native place as of the only possible place to live. Besides, the continuity of sibling relations and their harmony with each other are also quite vivid.

2.Openness through understanding of necessity in meeting other cultures:

The culture inside a community is not the one and only acceptable: there is an opportunity to know other cultures, which are not closed and ready to welcome members of other societies. The life in other cultures puts people against unknown things, but such challenges are important for their personal development.

\section{Group perception of the world:}

A man in this culture does not live alone: their unity is expressed through the integration with other people, i.e. with the family.

\section{Perception of the nature as an assisting} force

The natural forces are not seen as a danger. They act either as short-term obstacles, which are easy to cope with, or as directing ones. In this tale such natural force is the river. In any case, the nature does not have any character of unknownability or threat.

The world structure. The world is defined only by people. Such structure does not include any transcendental forces. The human world divides into: a place for the "home" and place for the "society". The main leading element is the nature, which serves as an assistant and guidance;

The purpose of activity is to develop personally and gain the experience to form a new family;

Algorithm. Personal development through the acquaintance with the society and acceptance of others' experience and knowledge followed by homecoming.

Participants. A man undergoing the development; the society as a "wealth of knowledge"; and natural guides.

An ideal person is one that has managed all the challenges, gained the necessary experience and returned to their native place.

The main idea grounding the Nenets society is an open perception of the world, where each member is given a guide represented by the family. Each member of the society plays particular, "their own" role, and the nature performs as an external, but still not aggressive force.

To draw the line, we shall note that the fairy tales of indigenous small-numbered peoples of the Krasnoyarsk Krai represent a unique archive of the perceptions on the world view, on humans' place in it, on balanced ways of interaction of the man with the world and other people.

The fairy tale is one of the types of folklore prose peculiar to the traditional culture and represents the basic form of children's literature. It constitutes a part of the education system, since it contains such ethic values as hymning for beauty, valor, strength, bravery; moral guides performing as the "rules of life", and also practical recommendation, pieces of advice, algorithms applicable in certain circumstances. 
Thus, the analysis of fairy tales as an important part of education, which clearly express the ideas about family models and world views, has a particular importance for understanding of the values belonging to the straight culture of some or another nation that in its turn is a necessary requirement for this culture to be preserved in the context of global integration.

Being a part of the children's literature, the fairy tale represents a way to form the person oriented on conservation of their traditions, and, moreover, the tale gives an opportunity to remember about the cultural origin and ethnic roots in the era of modern scientific technologies and different gadgets which make the human's life more comfortable.

We should also emphasize, that to some degree today's' existence of traditional cultures switch into a virtual reality. Thus, for example, the tales of indigenous small-numbered peoples of the Krasnoyarsk Krai can be found in the Internet [5], among the tales of other peoples. The majority of these tales are written in the Russian language, in the form in which they were collected by the Soviet scientists during the folk expeditions [30]. Consequently, in order to preserve the uniqueness of straight cultures of the Krasnoyarsk Krai's indigenous peoples in the most complete way, we should work towards recording the tales in their original language.

\section{References}

Jerome, K., Sweeney, K.A. (2014). Birth Parents' Portrayals in Children's Adoption Literature, In Journal of Family Issues, 35 (5), 677-704.

Nelson, C. (2012). Precocious Children and Childish Adults, In Age Inversion in Victorian Literature, 1-211.

Pearson, L. (2013). The Making of Modern Children's Literature in Britain, In Publishing and Criticism in the 1960s and 1970s, 1-218.

Archakova, O. B., Trifanova L. L. (2006). Mifologicheskie predstavleniia evenkov: po materialam narodnykh skazok [Mythological beliefs of the Evenks: on the material of folk fairy tales] Blagoveschensk: Izd-vo AmGU, 238 p.

Biblioteka skazok Khobobo [Khobobo fairy tales library]. Available at: http://www.hobobo.ru/

Dmitriev, I. (2005). Kontent-analiz: suschnost', zadachi, proceduri. Psi-faktor [Content analysis: essence, tasks and procedures. Psy-factor]. Available at: http://www.psyfactor.org/lib/k-a.htm

Gurskaia, M.A. (2012). Psihologicheskii i kul'turnii klimat semii v sovremennoi detskoi literature [Psychological and cultural climate in the modern children's literature], In Istoricheskaja i sotsial'noobrazovatel'naia mysl' [Historical and socio-educational ideas], 1, 196-200.

Ilibeikina, M.I. (2014). Osobennosti vizualno-antropologicheskikh issledovanii indigennikh narodov [Features of visual and anthropological analysis of indigenous peopels], In Sovremennie problemi nauki i obrazovaniia [Topical problems of science and education], 4, 594.

Isakovskaia, A. Iu. (2012). Detskaia skazka v russkoi sovetskoi literature (retseptsia mirovikh siuzhetov). Dissertatsiia na soiskanie uchenoi stepeni kandidata filologicheskikh nauk. Moskovskii gosudarstvennyj universitet imeni M.V. Lomonosova [The children's literature in the Russian Soviet literature: reception on the world stories. Cand. Sci. (Philology) thesis. Lomonosov Moscow State University].

Kicheva, E.D. (2015). Sovremennaia detskaia literatura ob osobikh detiah kak sredstvo vospitaniia toleratnosti [The modern pedagogical literature about special need children as the mean of tolerance 
education], In Teoreticheskie i prakticheskie aspekti razvitiia nauchnoi mysli v sovremennom mire [Theoretical and practical aspects of the scientific ideas development in the modern world], 240242.

Kim, A.A. (2011). Folklornii analiz $i$ klassifikatsiia khantiiskikh prozaicheskikh tekstov, zapisannikh Steiniz v 1936 god [The folklore analysis and classification of the prosaic Khanty texts collected by Steiniz in 1936], In Vestnik Tomskogo gosudarstvennogo pedagogicheskogo universiteta [Tomsk State Pedagogical University Bulletin], 3, 156-161

Kistova, A.V. (2013). Stanovlenie filosofii kultury kak metodologicheskoi osnovi gumanitarnogo znaniia [Development of the philosophy of culture as a methodological basis for humanities knowledge], In Sovremennie problemi nauki i obrazovaniia [Topical problems of science and education], 1, 401.

Kolesnik, M.A. (2014) Obzor izucheniia folklora korennikh narodov Severa [Review on the studies of folklore of indigenous peoples of the North] Litera, (3) 9 - 11.

Koptseva, N.P. (2014). K voprosu o gosudarstvennoi politike v oblasti sokhraneniia iazykov korennikh malochislennikh narodov Severa [On the problem of linguistic protection of the indigenous small-numbered peoples of the North], In Arktika i Sever [Arctic and North], 16, 34-40.

Koptseva, N.P., Bralkova A.V., Gerasimova A.A., Govorukhina Iu.A. i dr. (2015). Novaia artkritika na beregakh Yeniseia [The new art-critics on the Yenisei-river]. Krasnoyarsk, Siberian Federal University.

Koptseva, N.P., Nevolko N.N., Reznikova K.V. (2013). Formirovanie etnokulturnoi identichnosti $v$ sovremennoi Rossii s pomoschiu proizvedenii natsionalnogo iskusstva (na primere evenkiiskogo eposa i dekorativno-prikladnogo iskusstva) [Formation of the ethnocultural identity in the modern Russia through the national art works (on the example of Evenk epos and applied arts], In Pedagogika iskusstva [Pedagogics of art $], 1,1-15$.

Koptseva, N.P., Seredkina N.N. (2013). Konstruirovanie pozitivnoi etnicheskoi identichnosti $v$ polikul'turnoi sisteme [The construction of a positive ethnic identity in the multicultural system]. Krasnoyarsk, Siberian Federal University.

Koptseva, N.P., Sertakova E.A., Ilbeikina, M.I., Zamaraeva, Iu.S., Libakova N.M., Bakhova N.A., Luzan V.S., Reznikova K.V., Kistova A.V., Pimenova N.N., Nevolko N.N. (2011). Kultura korennikh $i$ malochislennikh narodov Severa v usloviiakh globalnikh transformatsii [The culture of indigenous smallnumbered peoples of the North in the context of global transformations]. Saint-Petersburg, $174 \mathrm{p}$.

Kuznetsova, T. F. (2015). Kulturnaia kartina mira kak iadro tezaurusa v konceptsii Vladimira Andreevicha Lukova [The cultural world view as the thesaurus core in the concept by Vladimir Lukov].

Osipova, M.V. (2015). K probleme klassifikatsii motivov v ainskikh volshebnikh skazkakh [On the problem of motives classification in the Ain fairy tales], In Sotsialnie i gumanitarnye nauki na Dalnem Vostoke [Social science and humanities in the Far East], 4 (48), 128-131.

Pimenova, N.N. (2014). Kulturnoe nasledie korennikh malochislennikh narodov Krasnoyarskogo kraia i sovremennye kulturnie praktiki [The cultural heritage of the Krasnoyarsk Krai's indigenous small-numbered peoples and the modern cultural practice], In Chelovek i kultura [The man and the culture], 2, 28-66.

Polenova, G.T. (2015). O chem mozhet rasskazat ketskaia skazka [What can Ket tales tell us about?], In Vestnik Voronezhskogo gosudarstvennogo universiteta: Lingvistika i mezhkulturnaia 
kommunikatsiia [Voronezh State University Bulletin: Linguistics and cross-cultural communication], 3, 52-55.

Pushkareva, E.T. (2003). Kartina mira v folklore i traditsionnikh predstavleniiakh nentsev: sistemno-fenomenologicheskii analiz. Avtoreferat dissertacii doktora istoricheskih nauk [The world view in the Nents folklore and traditional beliefs: the system and phenomenological analysis: extended abstract of Doctor. Sci. (History) thesis]. Moscow.

Razumovskaia, V.A. (2012). Izomeriia v lingvistike i perevodovedenii: rasshirenie kategorialnoi paradigm [Isomerism in linguistics and translation studies: expansion of the categorical paradigm], In Iazyk i kultura [Language and culture], 4 (20), 49-61.

Razumovskaia, V.A. (2015). Kognitivnie osobennosti avtorskogo perevoda poezii [Cognitive characteristics of the author's poetic translation], In Kognitivnie issledovaniia iazyka [Cognitive studies of the language], 22, 521-523.

Reznikova, K.V. (2014). K voprosu ob utochnenii poniatii «etnos» $i$ «etnichnost'» [On the problem of clarification of "ethnos" and "ethnicity" notions], In Sociodinamika [Social dynamics], 12, 90-102. Available at: http://e-notabene.ru/pr/article_13913.html

Reznikova, K.V. (2016). K voprosu ob epicheskom kulturnom nasledii korennikh malochislennikh narodov krasnoiarskogo kraia [On the problem of epic cultural heritage of the Krasnoyarsk Krai's indigenous small-numbered peoples]. Litera, 2, 20-34.

Savinova, S.V., Leontieva, T.P. (2014). Detskaia literatura kak sredstvo formirovaniia prirodovedcheskikh znanii u mladshikh shkolnikov [The children's literature as the mean of environmental knowledge formation in primary school], In Kontsept [Concept], 32, 11-15.

Sitnikova, A.A. (2014). Khudozhestvennaia interpretatsiia obraza zhizni na Severe $v$ proizvedeniiakh Rockwell Kent [Artistic interpretation of the Northern life style in the works by Rockwell Kent], In Sovremennie problemi nauki i obrazovaniia [Topical problems of science and education], 4, 593.

Skazki narodov Severa [Fairy tales of the indigenous peoples of the North]. Available at: http:// libatriam.net/read/365334/\#

Utkina, O.A. (2012). Gendernii aspekt $v$ detskoi literature. Chto chitaiut malchiki [The gender aspect in the children's literature.What do boys read?], In Vestnik Udmurtskogo universiteta: Filosofiia. Psihologiia. Pedagogika [Udmurt State University Bulletin: Philosophy. Psychology. Pedagogics], 3 (4), 79-83.

Vladislavleva, T.B. (2011). Kulturno-istoricheskoie nasledie kak resurs innovacionnogo razvitiia korennikh malochislennikh narodov Severa [Cultural and historical heritage as a resource for innovative development of indigenous communities of the North], In Vestnik Moskovskogo gosudarstvennogo lingvisticheskogo universiteta [Moscow State Linguistic University Bulletin], 608, 9-20.

Voskoboinikov, V.M. (2012). Detskaia literatura vchera i segodnia. A zavtra? [Children's literature of yesterday and today. And what about tomorrow?], In Voprosy literatury [Literature Matters], 5, $76-88$.

Voskobojnikov, M.G. (1967). O fol'klore jevenkov. V: Fol'klor jevenkov Pribajkal'ja. Ulan-Udje, Burjatskoe knizhnoe izdatel'stva, 3-21.

Zaharova, K.I. (2015). Etnokulturnye realii v folklore malochislennikh narodov respubliki Saha (Yakutiia) i inuitov Kanady (na materiale skazok) [Ethno-cultural realias of the small-numbered 
peopes of the Republic of Sakh (Yakutiia) and Canadian Innus (through the example of fairy tales)], In Novoe slovo v nauke i praktike: gipotezy i aprobatsiia rezultatov issledovanii [A breakthrough in science and practice: hypothesis and research approbations], 21, 32-35.

Zamaraeva, Iu.S. (2015). Globalnie transformatsii, kotorie perezhivajut indigennie narody Severa [The global problems undergone by the indigenous peoples of the North], In Sovremennie problemi nauki i obrazovaniia [Topical problems of science and education], 1(1), 1882.

\section{Детская литература коренных малочисленных народов Красноярского края}

Н.М. Либакова, К.И. Петрова

Сибирский федеральный университет Россия, 660041, Красноярск, пр. Свободный, 79

Статья посвящена изучению сказки как основного вида детской литературы коренных малочисленных народов Красноярского края. Сказка является особой прозаической формой фольклоpa, направленной на сохранение и трансляиию самобытных ценностей той или иной культуры, поддержание связи между поколениями. В статье посредством метода контент-анализа в сказках эвенков, нганасан, ненцев и кето обнаружены черты картины мира, характерной для культуры каждого из народов, а также выявлена модель семьи. Модели семьи уделено внимание, так как именно семья является первичнымм пространством формирования личности, формирования ее этнической идентичности и системы ценностных ориентиров. Также сказка рассматривается как уникальная форма, позволяющая сохранять самобытность культуры коренных малочисленных народов Красноярского края в условиях глобализации, гармонично сочетать цุенности традиционной культуры и современные достижения циивилизации.

Ключевые слова: детская литература, сказка, коренные малочисленные народы, Красноярский край, Север, картина мира, модель семьи, контент-анализ.

Статья написана при выполнении исследований по гранту Красноярского краевого фонда поддержки научной и научно-технической деятельности на тему: "Создание корпуса текстов для детей на родных языках (эвенкийский, ненеикий, нганасанский, долганский) как способ сохранения уникального культурного наследия коренных малочисленных народов Красноярского края».

Научная специильность: 24.00.01 - теория и история культуры. 